\title{
Fungsi Sistolik dan Diastolik Jantung pada Pasien Anak dengan Osteosarkoma yang Mendapat Terapi Doksorubisin Di RS Gipto Mangunkusumo
}

\author{
Kristin Handojo, Hikari Ambara Sjakti, Piprim B. Yanuarso, Arwin AP Akib \\ Departemen Ilmu Kesehatan Anak Fakultas Kedokteran Universitas Indonesia/Rumah Sakit Cipto \\ Mangunkusumo, Jakarta
}

\begin{abstract}
Latar belakang. Doksorubisin merupakan obat golongan antrasiklin yang penting dan efektif pada pengobatan tumor padat pada anak. Doksorubisin mencegah sintesis RNA dan DNA melalui proses interkalasi. Kardiotoksisitas dilaporkan paling banyak karena penggunaan doksorubisin tersebut sehingga penggunaannya masih terbatas.

Tujuan. Mengetahui fungsi jantung pada anak dengan osteosarkoma setelah mendapat terapi doksorubisin di RSCM.

Metode. Studi deskriptif potong lintang dilakukan di RSCM, Divisi Hematologi-Onkologi IKA dan Sub Bagian Onkologi Orthopedik dan Traumatologi, dengan menelusuri catatan registrasi dan rekam medis pasien anak dengan osteosarkoma sejak 1 Januari 2005 sampai dengan 31 Desember 2012.

Hasil. Terdapat 25 subjek penelitian, 21 di antaranya selesai menjalani kemoterapi dan mendapat total dosis kumulatif doksorubisin dengan rentang $300 \mathrm{mg} / \mathrm{m}^{2}$ sampai $675 \mathrm{mg} / \mathrm{m}^{2}$. Fungsi sistolik LV mengalami penurunan rerata fraksi ejeksi 3,3\% dan pemendekan 2,5\% setelah mendapat doksorubisin. Fungsi diastolik LV mengalami penurunan rerata rasio E/A 17,6\%. Sembilan dari 18 pasien yang selesai menjalani kemoterapi dan mendapat total dosis kumulatif doksorubisin $375 \mathrm{mg} / \mathrm{m}^{2}$ mengalami gangguan fungsi diastolik tidak disertai gangguan fungsi sistolik. Kardiomiopati dilatasi ditemukan pada satu pasien setelah mendapat dosis kumulatif doksorubisin $300 \mathrm{mg} / \mathrm{m}^{2}$ dan satu pasien setelah mendapat dosis $675 \mathrm{mg} / \mathrm{m}^{2}$. Pasien berusia $\geq 10$ tahun dan berjenis kelamin perempuan lebih banyak mengalami penurunan fungsi sistolik dan diastolik LV setelah mendapat doksorubisin.

Kesimpulan. Fungsi sistolik dan diastolik LV menurun setelah pasien mendapat terapi doksorubisin dengan dosis kumulatif $300 \mathrm{mg} / \mathrm{m}^{2}$. Penurunan fungsi diastolik mendahului penurunan fungsi sistolik LV. Dosis, usia, dan jenis kelamin perempuan dapat menjadi faktor risiko penurunan fungsi jantung setelah pemberian doksorubisin. Sari Pediatri 2014;16(3):149-56
\end{abstract}

Kata kunci: fraksi ejeksi, fraksi pemendekan, rasio E/A, osteosarkoma, doksorubisin

Alamat korespondensi:

Dr. Hikari Ambara Sjakti, Sp.A(K). Divisi Hematologi Onkologi. Departemen Ilmu Kesehatan Anak FKUI-RSCM. Jl. Salemba No.6, Jakarta 10430. Telp./Fax. (021)-3154020

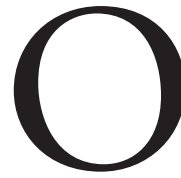

steosarkoma adalah tumor ganas primer tulang yang sering dijumpai pada anak dan remaja. ${ }^{1}$ Pada tahun 2008-2012, data Divisi Hematologi-Onkologi Ilmu Kesehatan 
Anak RS Cipto Mangunkusumo (IKA-RSCM) mencatat $31(2,8 \%)$ pasien dengan osteosarkoma dari 1109 pasien dengan keganasan. Perkembangan terapi multi modal yang meliputi kemoterapi neo-ajuvan dan ajuvan meningkatkan angka kesintasan pasien osteosarkoma sampai $60,1 \% .^{2}$ Kemoterapi pada osteosarkoma menggunakan protokol kemoterapi Werkgroep Kindertumouren, Emma Kinderziekenhuis, Academic Medical Center (WKT, EKZ, AMC, 1989) terdiri atas cisplatin $60 \mathrm{mg} / \mathrm{m}^{2}$, ifosfamid $3000 \mathrm{mg} / \mathrm{m}^{2}$, dan doksorubisin $25 \mathrm{mg} / \mathrm{m}^{2} /$ hari selama 3 hari setiap 3 minggu (total dosis kumulatif $375 \mathrm{mg} / \mathrm{m}^{2}$ ).

Doksorubisin merupakan obat golongan antrasiklin yang penting dan efektif pada pengobatan tumor padat pada anak. Doksorubisin mencegah sintesis ribonucleic acid (RNA) dan deoxyribonucleic acid (DNA) melalui proses interkalasi. ${ }^{3-7}$ Toksisitas terhadap jantung dilaporkan paling banyak karena penggunaan doksorubisin. Kardiotoksisitas merupakan salah satu komplikasi jangka panjang yang serius pada terapi kanker atau keganasan. Hingga saat ini, penggunaan antrasiklin masih terbatas karena kardiotoksisitas yang ditimbulkan. ${ }^{8-10}$

Dosis kumulatif maksimum antrasiklin yang aman agar kardiotoksisitas tidak terjadi masih belum diketahui. Sorensen $\mathrm{dkk}^{11}$ melaporkan penggunaan dosis kumulatif $>250-300 \mathrm{mg} / \mathrm{m}^{2}$ harus dihindarkan. Pendapat lain menyatakan total dosis kumulatif doksorubisin yang dianjurkan tidak lebih dari 550 $\mathrm{mg} / \mathrm{m}^{2}{ }^{12}$ Faktor risiko peningkatan kardiotoksisitas pada penggunaan anti-neoplastik adalah peningkatan dosis kumulatif obat, dosis per terapi, kecepatan saat pemberian, hipertensi, penyakit jantung yang mendasari, iradiasi mediastinum, usia muda saat diberikan kemoterapi, jenis kelamin perempuan, dan kombinasi dengan trastuzumab, siklofosfamid, dan ifosfamid. ${ }^{13}$

Panduan untuk pemantauan kardiotoksisitas yang universal belum ada. Pemantauan fungsi jantung dilakukan sebelum, selama, dan sesudah terapi berdasarkan data dasar, jadwal terapi, dan status klinis pasien. ${ }^{14}$ The Cardiology Committee of Children's Cancer Study Group merekomendasikan untuk menghentikan atau menurunkan dosis antrasiklin apabila terdapat gangguan fungsi sistolik ventrikel kiri (fraksi pemendekan $<29 \%$ melalui ekokardiografi atau fraksi ejeksi ventrikel kiri $<55 \%$ melalui angiokardiografi radionuklir). ${ }^{15}$ Rekomendasi ini dibantah oleh Lipshultz $\mathrm{dkk}^{16}$ karena modifikasi terapi antrasiklin untuk mengurangi kardiotoksisitas dapat meningkatkan kematian karena keganasan sehingga modifikasi dosis hanya dianjurkan apabila terbukti secara klinis terdapat kardiotoksisitas. ${ }^{17}$

Doksorubisin yang digunakan pada pengobatan osteosarkoma mengikuti protokol yang sudah ada dan dapat melebihi dosis kumulatif $300 \mathrm{mg} / \mathrm{m}^{2}$ sehingga berisiko terjadi kardiotoksisitas. Sampai saat ini, belum ada laporan mengenai gambaran evaluasi fungsi jantung terhadap penggunaan doksorubisin dengan dosis kumulatif minimal $250 \mathrm{mg} / \mathrm{m}^{2}$ sebagai bagian kemoterapi pada pasien osteosarkoma di IKARSCM.

\section{Metode}

Penelitian deskriptif potong lintang untuk mengetahui fungsi sistolik dan diastolik jantung pasien anak dengan osteosarkoma yang mendapat terapi doksorubisin dengan dosis kumulatif $250 \mathrm{mg} / \mathrm{m}^{2}$ atau lebih. Digunakan data rekam medis periode tahun 2005 sampai dengan 2012. Penelusuran catatan registrasi osteosarkoma dilakukan di Divisi Hematologi-Onkologi dan Sub Bagian Onkologi Orthopedik dan Traumatologi dan rekam medis pasien di RSCM. Populasi penelitian adalah semua anak yang menderita osteosarkoma, berobat di RSCM, dan mendapat terapi doksorubisin. Kriteria inklusi adalah anak berusia 0-18 tahun yang telah didiagnosis osteosarkoma dan mendapat kemoterapi doksorubisin dengan dosis kumulatif $250 \mathrm{mg} / \mathrm{m}^{2}$ atau lebih, memiliki data awal dan ulangan ekokardiografi termasuk data fraksi pemendekan, fraksi ejeksi, dan rasio E/A, serta memiliki data dosis doksorubisin yang didapat. Kriteria eksklusi adalah pasien yang menderita penyakit jantung bawaan, kelainan jantung sebelum kemoterapi, dan rekam medis tidak lengkap.

Kesimpulan hasil ekokardiografi merupakan interpretasi tim spesialis kardiologi anak di Divisi Kardiologi Anak RSCM. Gangguan fungsi sistolik ventrikel kiri (LV) apabila fraksi ejeksi $<54 \%$ dan atau fraksi pemendekan $<28 \% .{ }^{18}$ Gangguan fungsi sistolik ventrikel kanan (RV) apabila tricuspid annular plane systolic excursion (TAPSE) $<0,91 \mathrm{~cm}$ dan $>2,47 \mathrm{~cm} .{ }^{19}$ Fungsi diastolik ventrikel dinilai dari peak E velocity (E) adalah kecepatan pengisian ventrikel, peak $A$ velocity (A) adalah kecepatan selama kontraksi atrium. Nilai normal pada anak, peak E velocity (E) $0,91 \pm 0,11 \mathrm{~m} /$ detik, peak A velocity (A) $0,49 \pm 0,08 \mathrm{~m} /$ detik, dan rasio 
E/A $1,9 \pm 0,4$. Gangguan fungsi diastolik ventrikel kiri apabila $\mathrm{E} / \mathrm{A}<1,5$ dan $>2,3 .{ }^{18}$ Komplikasi jantung lain apabila terdapat pembesaran dari atrium atau ventrikel, gagal jantung kongestif, hipertensi pulmonal (tricuspid pressure gradient $>35 \mathrm{mmHg}$ ), ${ }^{20}$ atau adanya efusi perikardium. Data dianalisis dengan statistical package for the social sciences (SPSS) versi 17.0.

Persetujuan etik penelitian diperoleh dari Komisi Etik Penelitian Fakultas Kedokteran Universitas Indonesia melalui Surat Keterangan Lolos Kaji Etik Nomor 130/H2.F1/ ETIK/2013 tertanggal 4 Maret 2013.

\section{Hasil}

Selama tahun 2005 sampai dengan 2012, terdapat 103 pasien tercatat pada data registrasi. Saat pencarian data rekam medis untuk diagnosis osteosarkoma yang menjalani kemoterapi didapatkan 50 pasien. Penelusuran lebih lanjut didapatkan 35 pasien yang memiliki kelengkapan data kemoterapi dan ekokardiografi, tetapi 5 pasien tidak selesai kemoterapi dan 5 pasien sedang kemoterapi. Di samping itu, dosis doksorubisin belum mencapai $250 \mathrm{mg} / \mathrm{m}^{2}$ sehingga terdapat 25 pasien yang memenuhi kriteria inklusi.

Rentang usia subjek adalah 3 tahun 7 bulan hingga 16 tahun 4 bulan dengan median usia saat diagnosis adalah 12 tahun 7 bulan. Mayoritas subjek berjenis kelamin perempuan dengan rasio perempuan : laki-laki adalah 1,3:1 (Tabel 1).

Lokasi tumor paling banyak ditemukan terdapat di femur distal (10/25) diikuti femur proksimal (5/25), dan tibia proksimal $(5 / 25)$. Sebagian besar pasien 15/25 mendapat kemoterapi neo-ajuvan, limb salvage, dilanjutkan dengan kemoterapi ajuvan.

Satu pasien hanya mendapat $225 \mathrm{mg} / \mathrm{m}^{2}$ karena didahului dengan retinoblastoma satu tahun sebelumnya. Selanjutnya, dalam pemantauan respon kemoterapi terhadap osteosarkoma tidak ada dan timbul tumor baru di femur dekstra. Hal tersebut disimpulkan sebagai metastasis retinoblastoma sehingga protokol kemoterapi diubah menggunakan vinkristin, etoposid, dan karboplatin dosis tinggi. Satu pasien hanya mendapat $300 \mathrm{mg} / \mathrm{m}^{2}$ karena dalam pemantauan terdapat kardiomiopati dilatasi ringan, penurunan fungsi sistolik dan diastolik, serta dilatasi atrium dan ventrikel sinistra. Pasien yang mendapat dosis doksorubisin $450 \mathrm{mg} / \mathrm{m}^{2}$ karena terdapat osteosarkoma residif sehingga mendapat kemoterapi tambahan 3 siklus, tetapi doksorubisin tidak dilanjutkan setelah dosis kumulatif $450 \mathrm{mg} / \mathrm{m}^{2}$. Pasien yang mendapat dosis terbesar, $675 \mathrm{mg} / \mathrm{m}^{2}$, karena osteosarkoma relaps setelah 4 tahun pasien menyelesaikan kemoterapi sehingga mendapatkan kemoterapi 2 kali, masingmasing 6 siklus, tetapi doksorubisin tidak dilanjutkan setelah dosis kumulatif $675 \mathrm{mg} / \mathrm{m}^{2}$.

Tabel 1. Karakteristik subjek penelitian

\begin{tabular}{|c|c|}
\hline Karakteristik & Jumlah $(\mathrm{n}=25)$ \\
\hline \multicolumn{2}{|l|}{ Jenis kelamin } \\
\hline Lelaki & 11 \\
\hline Perempuan & 14 \\
\hline \multicolumn{2}{|l|}{ Kelompok usia (tahun) } \\
\hline$<10$ & 7 \\
\hline$\geq 10$ & 18 \\
\hline \multicolumn{2}{|l|}{ Diameter tumor $(\mathrm{cm})$} \\
\hline$<12$ & 10 \\
\hline$\geq 12$ & 15 \\
\hline \multicolumn{2}{|l|}{ Lokasi tumor } \\
\hline Femur & 15 \\
\hline Tibia & 7 \\
\hline Humerus & 1 \\
\hline Metatarsal & 1 \\
\hline Mandibular & 1 \\
\hline \multicolumn{2}{|l|}{ Lama gejala (bulan) } \\
\hline$<3$ & 8 \\
\hline$\geq 3$ & 17 \\
\hline \multicolumn{2}{|l|}{ Staging } \\
\hline IIB & 17 \\
\hline III & 8 \\
\hline \multicolumn{2}{|l|}{ Jenis pembedahan } \\
\hline Limb ablasi & 12 \\
\hline Limb salvage & 13 \\
\hline \multicolumn{2}{|l|}{ Kemoterapi } \\
\hline Neo-ajuvan & 3 \\
\hline Ajuvan & 7 \\
\hline Neo-ajuvan dan ajuvan & 15 \\
\hline \multicolumn{2}{|c|}{ Extracoporeal irradiation (ECI) } \\
\hline $\mathrm{Ya}$ & 13 \\
\hline Tidak & 12 \\
\hline \multicolumn{2}{|l|}{ Dosis doksorubisin $\left(\mathrm{mg} / \mathrm{m}^{2}\right)$} \\
\hline 225 & 1 \\
\hline 300 & 4 \\
\hline 375 & 18 \\
\hline 450 & 1 \\
\hline 675 & 1 \\
\hline
\end{tabular}


Kristin Handojo dkk: Fungsi sistolik dan diastolik jantung dengan osteosarkoma yang mendapat terapi doksorubisin

Tabel 2. Karakteristik luaran osteosarkoma

\begin{tabular}{lccc}
\hline Luaran & $\begin{array}{c}\text { Hidup } \\
\mathrm{n}=13\end{array}$ & $\begin{array}{c}\text { Meninggal } \\
\mathrm{n}=12\end{array}$ & $\begin{array}{c}\text { Total } \\
\mathrm{n}=25\end{array}$ \\
\hline $\begin{array}{l}\text { Kemoterapi status } \\
\quad \text { Selesai kemoterapi }\end{array}$ & 13 & 8 & 21 \\
$\quad$ Tidak selesai & 0 & 4 & 4 \\
$\begin{array}{l}\text { Metastasis } \\
\quad \text { Ya }\end{array}$ & 1 & 7 & 8 \\
$\quad$ Tidak & 12 & 5 & 17 \\
Lokasi metastasis & & & \\
$\quad$ Paru & 0 & 3 & 3 \\
Tulang lain & 0 & 1 & 1 \\
Paru dan tulang lain & 1 & 0 & 1 \\
Hematopoiesis & 0 & 1 & 1 \\
SSP & 0 & 1 & 1 \\
Abdomen & 0 & 1 & 1 \\
$\quad$ Tidak ada & 12 & 5 & 17 \\
ECI & & & \\
$\quad$ Ya & 8 & 5 & 13 \\
$\quad$ Tidak & 5 & 7 & 12 \\
\hline
\end{tabular}

ECI: extracoporeal irradiation

Dua puluh satu pasien selesai menjalani kemoterapi, tiga pasien tidak selesai karena meninggal, dan satu pasien ganti protokol. Terdapat metastasis pada $8 / 25$ pasien dan 4/25 ke paru-paru. Tiga belas pasien selesai menjalani kemoterapi dan masih hidup berdasarkan catatan registrasi dan follow-up lewat telepon. Dua belas pasien meninggal, dua gagal ginjal, satu infeksi, tiga metastasis paru, satu metastasis hematopoiesis, dua tidak selesai kemoterapi, dua tidak respon terhadap kemoterapi, dan satu infiltrasi sistem saraf pusat disertai kardiomiopati dilatasi yang sudah dilakukan amputasi dan deartikulasi, mendapat kemoterapi ajuvan 4 siklus dan pasien akhirnya terapi paliatif. Satu pasien yang
Tabel 4. Profil ekokardiografi subjek penelitian $(\mathrm{n}=25)$

\begin{tabular}{lcc}
\hline Profil ekokardiografi & $\begin{array}{c}\text { Sebelum } \\
\mathrm{n}\end{array}$ & $\begin{array}{c}\text { Sesudah } \\
\mathrm{n}\end{array}$ \\
\hline Dilatasi LV & 0 & 4 \\
Dilatasi LA & 0 & 1 \\
Efusi perikardium & 0 & 0 \\
Fungsi sistolik ventrikel kiri & & \\
$\quad$ Normal & 25 & 23 \\
$\quad$ Tidak normal & 0 & 2 \\
Fungsi diastolik ventrikel kiri & & \\
$\quad$ Normal & 21 & 12 \\
$\quad$ Tidak normal & 4 & 13 \\
\hline
\end{tabular}

LV: left ventricle, LA: left atrium

relaps setelah 4 tahun menyelesaikan kemoterapinya disertai metastasis ke paru, masih hidup saat ini, tetapi dengan kardiomiopati dilatasi dan trombus di atrium sinistra sehingga mendapat terapi aspirin, furosemid, kaptopril, dan digoksin. Pasien yang masih hidup sebagian besar menjalani ECI dan limb salvage (Tabel 2).

Penurunan fungsi jantung didapatkan setelah subjek mendapat terapi doksorubisin. Rerata penurunan fraksi ejeksi 3,3\%, fraksi pemendekan 2,5\%, rasio E/A 0,3 (17,6\%), dan TAPSE 0,7 mm (Tabel 3).

Satu pasien diketahui mengalami dilatasi LA setelah mendapat dosis kumulatif doksorubisin 300 $\mathrm{mg} / \mathrm{m}^{2}$ dengan rasio LA/Ao 1,61. Dilatasi LV dialami 4/25 pasien, dua setelah mendapat dosis kumulatif doksorubisin $300 \mathrm{mg} / \mathrm{m}^{2}$ dan dua lainnya setelah mendapat dosis $375 \mathrm{mg} / \mathrm{m}^{2}$. Tidak ada pasien dengan efusi perikardium sebelum dan sesudah mendapat doksorubisin. Fungsi sistolik ventrikel kiri ditemukan tidak normal pada dua pasien. Satu pasien memiliki fraksi ejeksi yang menurun dari 70,1\% menjadi

Tabel 3. Fungsi jantung pasien anak dengan osteosarkoma $(\mathrm{n}=25)$

\begin{tabular}{lccc}
\hline Fungsi jantung & $\begin{array}{c}\text { Sebelum mendapat } \\
\text { doksorubisin } \\
\text { Rerata (SB) }\end{array}$ & $\begin{array}{c}\text { Sesudah mendapat } \\
\text { doksorubisin } \\
\text { Rerata (SB) }\end{array}$ & $\begin{array}{c}\text { Perbedaan rerata } \\
\text { (IK95\%) }\end{array}$ \\
\hline $\begin{array}{l}\text { Fungsi sistolik LV } \\
\quad \text { Fraksi ejeksi (\%) }\end{array}$ & $67,5(6,0)$ & $64,2(7,3)$ & $3,3(0,57-5,98)$ \\
$\quad$ Fraksi pemendekan (\%) & $36,6(4,1)$ & $34,1(5,6)$ & $2,5(0,65-4,52)$ \\
$\begin{array}{l}\text { Fungsi diastolik LV } \\
\quad \text { Rasio E/A }\end{array}$ & $1,7(0,3)$ & $1,4(0,3)$ & $0,3(0,12-0,44)$ \\
$\begin{array}{l}\text { Fungsi sistolik RV } \\
\text { TAPSE (mm) }\end{array}$ & $17,4(2,6)$ & $16,7(2,7)$ & $0,7(-1,08-2,4)$ \\
\hline
\end{tabular}

LV: left ventricle, RV: right ventricle, TAPSE: tricuspid annular plane systolic excursion 
$45,5 \%$ dan fraksi pemendekan menurun dari 38,1\% menjadi 22,5\% setelah mendapat total dosis kumulatif doksorubisin $300 \mathrm{mg} / \mathrm{m}^{2}$. Pasien yang lain didapatkan penurunan fraksi ejeksi dari $61,3 \%$ menjadi $51,3 \%$ dan fraksi pemendekan dari 32,3\% menjadi $25,7 \%$ setelah mendapat total dosis kumulatif doksorubisin $675 \mathrm{mg} /$ $\mathrm{m}^{2}$. Fungsi diastolik ventrikel kiri ditemukan tidak normal pada 13 pasien setelah mendapat doksorubisin. Dua pasien di antaranya yang menunjukkan gejala kardiomiopati dilatasi mendapat terapi. Dua pasien tersebut memiliki rasio E/A yang rendah, $0,42 \mathrm{~m} /$ detik dan $0,74 \mathrm{~m} /$ detik setelah mendapat doksorubisin 300 $\mathrm{mg} / \mathrm{m}^{2}$, sedangkan pasien lain memiliki rasio $\mathrm{E} / \mathrm{A}<1,5$ $\mathrm{m} /$ detik dengan rentang 1,19-1,49 m/detik. Setelah diketahui terdapat penurunan fungsi sistolik dan diastolik ventrikel kiri, doksorubisin tidak dilanjutkan pada kemoterapi selanjutnya (Tabel 4).

Fungsi sistolik dan diastolik LV menurun setelah pasien mendapat total dosis kumulatif doksorubisin $300 \mathrm{mg} / \mathrm{m}^{2}$. Penurunan fungsi sistolik dan diastolik jantung terdapat pada satu pasien yang mendapat total dosis kumulatif doksorubisin $300 \mathrm{mg} / \mathrm{m}^{2}$, tidak disertai gejala klinis. Penurunan fungsi diastolik jantung mendahului penurunan fungsi sistolik. Hal tersebut terlihat pada sebagian besar pasien (18/25) yang selesai menjalani kemoterapi dan mendapat total dosis kumulatif doksorubisin $375 \mathrm{mg} / \mathrm{m}^{2}$. Didapatkan 9/18 (50\%) pasien dengan gangguan fungsi diastolik tanpa disertai gangguan sistolik. Satu pasien yang mendapat total dosis kumulatif doksorubisin 450 $\mathrm{mg} / \mathrm{m}^{2}$ mengalami gangguan fungsi diastolik tanpa gangguan sistolik. Satu pasien yang mendapat total dosis kumulatif doksorubisin $675 \mathrm{mg} / \mathrm{m}^{2}$ mengalami gangguan fungsi sistolik dan diastolik dengan kardiomiopati dilatasi dan trombus pada atrium sinistra, tidak disertai gejala klinis. Pasien mendapat terapi heparin, kemudian dilanjutkan aspirin, furosemid, kaptopril, dan digoksin. Lebih banyak proporsi pasien usia $\geq 10$ tahun dan berjenis kelamin perempuan dengan penurunan fungsi sistolik dan diastolik jantung setelah mendapat doksorubisin.

\section{Pembahasan}

Sebagian besar subjek adalah perempuan (14/25) dengan rasio perempuan:laki-laki adalah 1,3:1. Proporsi sampel tersebut berbeda dengan penelitian Geller $\mathrm{dkk}^{21}$ dan Mirabello $\mathrm{dkk}^{22}$ yang melaporkan jumlah subjek laki-laki lebih banyak, yaitu 1,43:1. Saat ini belum terdapat data epidemiologi yang menyatakan insiden osteosarkoma lebih banyak pada jenis kelamin tertentu. Insiden paling banyak pada laki-laki usia 15-19 tahun dan perempuan usia 10-14 tahun. Subjek dalam penelitian ini berusia 3 tahun 7 bulan hingga 16 tahun 4 bulan dengan median usia saat diagnosis 12 tahun 7 bulan. Hal tersebut serupa dengan penelitian Yang dkk, ${ }^{23}$ di Hongkong, yang melaporkan median usia subjeknya 13 tahun. Penelitian Yang dkk melaporkan lokasi paling sering ditemukan pada femur distal (45\%), tibia proksimal (22\%), dan femur proksimal (6\%). ${ }^{23}$ Bielack $\mathrm{dkk}^{24}$ dan Rech $\mathrm{dkk}^{25}$ melaporkan lokasi paling sering pada daerah metafisis tulang panjang pada ekstremitas, umumnya sekitar lutut.

Pada penelitian ini didapatkan $17 / 25$ pasien stage IIB dan 8/25 stage III berdasarkan kriteria Enneking. Stadium Musculoskeletal Tumor Society (MTS) berdasarkan kriteria Enneking yang digunakan pada osteosarkoma adalah 3 kriteria berdasarkan grade tumor, ekstensi tumor (intra atau ekstra kompartemental), serta adanya metastasis. ${ }^{26,27}$

Sebagian besar pasien 15/25 mendapat kemoterapi neo-ajuvan, limb salvage, dilanjutkan dengan kemoterapi ajuvan. Terapi untuk osteosarkoma yang direkomendasikan adalah reseksi dengan hasil margin bebas tumor dan kemoterapi sistemik-walaupun tumor primer telah direseksi total karena untuk mencegah metastasis mikroskopis. Hal tersebut ditemukan lebih banyak dibandingkan penelitian Sihombing $\mathrm{dkk}^{28}$ pada pasien anak dengan osteosarkoma di RSCM, 22 pasien yang dilakukan kemoterapi, 15 neo-ajuvan, 5 ajuvan, dan 2 mendapat kombinasi kemoterapi neo-ajuvan dan ajuvan.

Metastasis terdapat pada $8 / 25$ pasien dan $4 / 25$ metastasis ke paru-paru. Telaah yang dilakukan oleh Geller $\mathrm{dkk}^{21}$ melaporkan 10\%-20\% pasien ditemukan metastasis makroskopis dan $80 \%$ pasien terdapat metastasis mikroskopis. Metastasis berkembang secara hematogen dengan lokasi metastasis yang paling sering adalah paru-paru diikuti tulang lain. Penelitian Rech-di Brazil meliputi pasien osteosarkoma usia 3-22 tahun-melaporkan bahwa adanya metastasis merupakan faktor prognosis yang buruk dengan 5-year survival rate $<20 \%$.

Ejeksi fraksi dan fraksi pemendekan LV yang diukur dengan ekokardiografi merupakan indikator utama untuk evaluasi disfungsi jantung dan prediktor 
untuk morbiditas dan mortalitas. Swain $\mathrm{dkk}^{29}$ melaporkan terdapat $1 \%-2 \%$ pasien gagal jantung kongestif pada dosis kumulatif doksorubisin 300 $\mathrm{mg} / \mathrm{m}^{2}, 5 \%$ pada dosis $400 \mathrm{mg} / \mathrm{m}^{2}$, meningkat $16 \%$ pada dosis $500 \mathrm{mg} / \mathrm{m}^{2}, 26 \%$ pada dosis $550 \mathrm{mg} / \mathrm{m}^{2}$, dan $48 \%$ pada dosis $700 \mathrm{mg} / \mathrm{m}^{2}$. Pada penelitian ini, terdapat satu pasien dengan kardiomiopati dilatasi pada dosis kumulatif doksorubisin $400 \mathrm{mg} / \mathrm{m}^{2}$ dan satu pasien yang mendapat sampai $675 \mathrm{mg} / \mathrm{m}^{2}$.

Postma dkk ${ }^{30}$ melaporkan 41 pasien osteosarkoma dan 7 pasien fibrous histiocytoma malignant, pada tulang terdapat $26 \%$ pasien memiliki fraksi pemendekan $<29 \%$ pada ekokardiografi. Pasien tersebut menggunakan dosis total doksorubisin $225-550 \mathrm{mg} / \mathrm{m}^{2}$. Ditemukan pula dua pasien fungsi sistolik ventrikel kiri tidak normal, satu pasien dengan fraksi ejeksi $51,3 \%$ dan fraksi pemendekan $25,7 \%$ (mendapat dosis kumulatif doksorubisin $300 \mathrm{mg} / \mathrm{m}^{2}$ ), dan satu pasien dengan fraksi ejeksi $45,5 \%$ dan fraksi pemendekan 22,5\% (mendapat dosis kumulatif doksorubisin 675 $\left.\mathrm{mg} / \mathrm{m}^{2}\right)$.

Fungsi diastolik ventrikel kiri ditemukan tidak normal (rasio E/A <1,5) pada 13 pasien setelah mendapat terapi doksorubisin. Sebelas pasien memiliki rentang rasio E/A 1,19-1,49. Rasio E/A dapat menurun saat inspirasi pada anak normal, kecepatan peak $\mathrm{E}$ mitral menurun $8 \%$, kecepatan peak A tetap, dan rasio E/A dapat menurun 14\% sehingga rasio E/A menurun menjadi $1,29 .{ }^{18}$ Dua pasien memiliki rasio E/A 0,42 dan 0,74 menunjukkan gejala kardiomiopati dilatasi dan mendapat terapi. Schmitt $\mathrm{dkk}^{4}$ melaporkan bahwa anak yang mendapat terapi antrasiklin dapat terjadi penurunan fungsi diastolik ventrikel kiri sebelum penurunan fungsi sistolik. Dorup $\mathrm{dkk}^{6}$ melaporkan bahwa abnormalitas fungsi diastolik berhubungan dengan peningkatan dosis antrasiklin karena adanya gangguan relaksasi LV dan penurunan kecepatan peak E mitral.

Terdapat empat pasien dengan dilatasi LV, dua pasien dengan penurunan fungsi jantung sistolik dan diastolik yang mendapat terapi. Scott $\mathrm{dkk}^{31}$ melaporkan kardiotoksisitas doksorubisin yang terjadi dalam satu tahun terapi adalah dilatasi LV yang progresif, penipisan dinding LV, dan penurunan kontraktilitas jantung.

Pasien yang berusia $\geq 10$ tahun lebih banyak mengalami penurunan fungsi sistolik dan diastolik setelah mendapat doksorubisin. Hal tersebut berbeda dengan laporan Khan $\mathrm{dkk}^{13}$ bahwa usia muda saat mendapat kemoterapi merupakan faktor risiko peningkatan kardiotoksisitas pada penggunaan anti-neoplastik. Perbedaan ini mungkin akibat populasi usia pasien pada penelitian ini lebih banyak ditemukan berusia $\geq 10$ tahun. Proporsi jenis kelamin perempuan dengan penurunan fungsi sistolik dan diastolik jantung setelah mendapat doksorubisin lebih besar pada penelitian ini. Hal tersebut serupa dengan laporan Khan bahwa jenis kelamin perempuan merupakan faktor risiko peningkatan kardiotoksisitas pada penggunaan anti-neoplastik karena persentase lemak tubuh yang lebih tinggi dapat menyebabkan konsentrasi obat lebih tinggi di dalam sel.

Keterbatasan penelitian deskriptif ini adalah tidak dapat dibuat hubungan kesimpulan antara dosis kumulatif doksorubisin yang digunakan dengan kejadian penurunan fungsi jantung pada anak dengan osteosarkoma setelah mendapat terapi doksorubisin. Pengumpulan data bersifat retrospektif yang mengandalkan data dari rekam medis sehingga data yang diperoleh terbatas dengan yang tercantum dalam rekam medis dan tidak memberikan informasi pemeriksaaan fisis secara lengkap.

\section{Kesimpulan}

Fungsi sistolik LV dan diastolik LV menurun setelah pasien mendapat terapi doksorubisin dengan dosis kumulatif $300 \mathrm{mg} / \mathrm{m}^{2}$. Penurunan fungsi diastolik mendahului penurunan fungsi sistolik LV. Dilatasi LV merupakan komplikasi pada 4/25 pasien-2/25 pasien dengan dosis kumulatif doksorubisin $300 \mathrm{mg} /$ $\mathrm{m}^{2}$ dan $2 / 25$ dengan dosis kumulatif doksorubisin $375 \mathrm{mg} / \mathrm{m}^{2}$-dan dilatasi LA merupakan komplikasi pada $1 / 25$ pasien setelah mendapat dosis kumulatif doksorubisin $300 \mathrm{mg} / \mathrm{m}^{2}$. Kardiomiopati dilatasi ditemukan pada satu pasien setelah mendapat dosis kumulatif doksorubisin $300 \mathrm{mg} / \mathrm{m}^{2}$ dan satu pasien setelah mendapat dosis $675 \mathrm{mg} / \mathrm{m}^{2}$. Pasien berusia $\geq 10$ tahun dan berjenis kelamin perempuan lebih banyak mengalami penurunan fungsi sistolik dan diastolik LV setelah mendapat doksorubisin.

Kelengkapan data pemeriksaan fisis mencakup tekanan darah masih merupakan kendala utama sehingga, sebaiknya, data pemeriksaan fisis yang lengkap disertai dengan pemantauan selama kemoterapi diperlukan untuk menunjang penelitian selanjutnya. Pemantauan ekokardiografi serial setelah 
mendapat doksorubisin dosis kumulatif $>250 \mathrm{mg} / \mathrm{m}^{2}$ sebaiknya dilakukan setiap sebelum siklus kemoterapi berikutnya, setelah selesai menjalani kemoterapi, dan kemudian setiap 3 bulan. Pemantauan ekokardiografi serial perlu ditambahkan pada protokol kemoterapi osteosarkoma. Penelitian lanjutan secara prospektif setelah perbaikan pemantauan ekokardiografi agar didapatkan data yang valid untuk mengetahui adakah hubungan dosis kumulatif doksorubisin dan faktor risiko yang memengaruhi dengan penurunan fungsi jantung pada pasien anak dengan osteosarkoma setelah mendapat doksorubisin.

\section{Daftar pustaka}

1. Arndt CAS. Malignant tumors of bone. Dalam: Kliegman RM, Stanton BF, Geme JWS, Schor NF, Behrman RE, penyunting. Nelson textbook of pediatrics. Edisi ke-19. Philadelphia: Saunders Elsevier; 2011.h.1763-5.

2. Bacci G, Longhi A, Versari M, Mercuri M, Briccoli A, Picci P. Prognostic factors for osteosarcoma of the extremity, treated with neoadjuvant chemotherapy:15year experience in 789 patients treated a single institution. Cancer 2006; 106:1154-61.

3. Sherief LM, Kamal AG, Khalek EA, Kamal NM, Soliman AAA, Esh AM. Biomarkers and early detection of late onset anthracycline-induced cardiotoxicity in children. Hematol 2012;17:151-6.

4. Schmitt K, Tulzer G, Merl M, Aichhorn A, Grillenberger A, Wiesinger G, dkk. Early detection of doxorubicin and daunorubicin cardiotoxicity by echocardiography: diastolic versus systolic parameters. Eur J Pediatr 1995;154:201-4.

5. Baysal T, Koksal Y, Oran B, Sen M, Unal E, Cimen D. Cardiac functions evaluated with tissue doppler imaging in childhood cancers treated with anthracyclines. Pediatr Hematol Oncol 2010;27:13-23.

6. Dorup I, Levit G, Sullivan I, Sorensen K. Prospective longitudinal assessment of late anthracycline cardiotoxicity after childhood cancer: the role of diastolic function. Heart 2004;90:1214-6.

7. van der Pal HJ, van Dalen EC, Hauptmann M, Kok WE, Caron $\mathrm{HN}$, van den Bos C, dkk. Cardiac function in 5-year survivors of childhood cancer. Arch Intern Med 2010;170:1247-55.

8. Creutzig U, Diekamp S, Zimmermann M, Reinhardt D. Longitudinal evaluation of early and late anthracycline cardiotoxicity in children with AML. Pediatr Blood
Cancer 2007;48:651-62.

9. Sutaryo. Onkologi: prinsip kemoterapi pada kanker anak. Dalam: Permono HB, Sutaryo, Ugrasena IDG, Windiastuti E, Abdulsalam M, penyunting. Buku ajar hematologi-onkologi anak. Edisi ke-3. Jakarta: Badan penerbit IDAI; 2010.h.227-35.

10. Vandecruys E, Mondelaers V, Wolf DD, Benoit Y, Suys B. Late cardiotoxicity after low dose of anthracycline therapy for acute lymphoblastic leukemia in childhood. J Cancer Surviv 2012;6:95-101.

11. Sorensen K, Levitt GA, Bull C, Dorup I, Sullivan ID. Late anthracycline cardiotoxicity after childhood cancer. Cancer 2003;97:1991-8.

12. Pfizer Australia PtyLtd. Product information adriamycin. Diakses tanggal 8 Januari 2013.Diunduh dari: http:// www. medicines.org.aulfiles/pfpadrii.pdf.

13. Khan AC, Srinivasan S, Czuczman MS. Prevention and management of cardiotoxicity from antineoplastic therapy. J Support Oncol 2004;2:251-66.

14. Pfeffer B, Tziros C, Katz RJ. Current concepts of anthracycline cardiotoxicity: pathogenesis, diagnosis and prevention. Br J Cardiol 2009; 16:85-9.

15. Steinherz LJ, Graham T, urwitz R, Sondheimer HM, Schwartz RG, Shaffer EM, dkk. Guidelines for cardiac monitoring of children during and after anthracycline therapy: report of the Cardiology Committee of the Childrens Cancer Study Group. Pediatrics 1992;89:9429.

16. Lipshultz SE, Sanders SP, Goorin AM, Krischer JP, Sallan SE, Colan SD. Monitoring for anthracycline cardiotoxicity. Pediatrics 1994;93:433-7.

17. Park MK. Primary myocardial disease. Dalam: Park MK, penyunting. Pediatric cardiology for practitioners. Edisi ke-5. Philadelphia: Mosby; 2007.h.409-33.

18. Mertens LL, Friedberg MK. Echocardiographic assessment of cardiac dimensions, cardiac function, and valve function. Dalam: Allen HD, Driscoll DJ, Shaddy RE, Feltes TF, penyunting. Moss and Adams' heart disease in infants, children and adolescents including the fetus and young adult. Edisi ke-8. Philadelphia: Lippincott Williams and Wilkins; 2012.h.172-206.

19. Koestenberger M, Ravekes W, Everett AD, Stueger HP, Heinzl B, Gamillscheg A dkk. Right ventricular function in infants, children and adolescents: reference values of the tricuspid annular plane systolic excursion (TAPSE) in 640 healthy patients and calculation of $\mathrm{z}$ score values. J Am Soc Echocardiogr 2009;22:715-9.

20. Park MK. Noninvasive techniques. Dalam: Park MK, penyunting. Pediatric cardiology for practitioners. Edisi 
ke-5. Philadelphia: Mosby; 2007.h.118-38.

21. Geller DS, Gorlick R. Osteosarcoma: a review of diagnosis, management, and treatment strategies. Clin Advances Hematol Oncol 2010;8:705-18.

22. Mirabello L, Troisi RJ, Savage SA. International osteosarcoma incidence patterns in children and adolescents, middle ages and elderly persons. Int J Cancer 2009;125:229-34.

23. Yang JYK, Cheng FWT, Wong KC, Lee V, Leung WK, Shing MWK, dkk. Initial presentation and management of osteosarcoma, and its impact on disease outcome. Hong Kong Med J 2009; 15:434-9.

24. Bielack S, Carrle D, Casali PG. Osteosarcoma: ESMO clinical recommendations for diagnosis, treatment and follow-up. Ann Oncol 2009;20:137-9.

25. Rech A, Castro CG, Mattei J, Gregianin L, Leone LD, David A, dkk. Clinical features in osteosarcoma and prognostic implications. J Pediatr (Rio J) 2004;80:65-70.

26. Enneking WF, Spanier SS, Goodman MA. A system for the surgical staging of musculoskeletal sarcoma. Clin Orthop Relat Res 1980;153:106-20.

27. Jawad MU, Scully SP. Enneking Classification: Benign and Malignant Tumors of the Musculoskeletal System. Clin Orthop Relat Res 2010;468:2000-2.

28. Sihombing TY, Windiastuti E, Gatot D. Osteosarkoma pada anak di RS. Dr Cipto Mangunkusumo Jakarta. Sari Pediatri 2009;11:179-83.

29. Swain SM, Whaley FS, Ewer MS. Congestive heart failure in patients treated with doxorubicin. Cancer 2003;97:2869-79.

30. Postma A, Bink-Boelkens MTE, Beaufort-Krol GCM, Kengen RAM, Elzenga NJ, Schasfoort-van Leeuwen MJM, $\mathrm{dkk}$. Late cardiotoxicity after treatment for a malignant bone tumor. Med Pediatr Oncol 1996;26:230-7.

31. Scott JM, Khakoo A, Mackey JR, Haykowsky MJ, Douglas PS, Jones LW. Modulation of anthracyclineinduced cardiotoxicity by aerobic exercise in breast cancer. Circulation 2011;124:642-50. 